\title{
Serological and molecular investigation of Newcastle disease in household chicken flocks and associated markets in Eastern Shewa zone, Ethiopia
}

Hassen Chaka ${ }^{*}$, Flavie Goutard, Patricia Gil, Celia Abolnik, Renata Servan de Almeida, Shahn Bisschop, Peter N. Thompson

Hassen Chaka, Celia Abolnik, Shahn Bisschop, and Peter N. Thompson

University of Pretoria, Faculty of Veterinary Science, Department of Production Animal Studies, Private

Bag X04, Onderstepoort, 0110, Pretoria, South Africa

Hassen Chaka

National Animal Health Diagnostic and Investigation Centre, P.O.Box:04, Sebata, Ethiopia

Flavie Goutard

CIRAD, AGIRs Unit, Campus International de Baillarguet, 34398 Montpellier Cedex 5, France

Patricia Gil, Renata and Servan de Almeida

CIRAD, Bios Department, Campus International de Baillarguet, 34398 Montpellier Cedex 5, France

\section{Celia Abolnik}

University of Pretoria, Faculty of Veterinary Science, Department of Production Animal Studies, Private

Bag X04, Onderstepoort, 0110, Pretoria, South Africa and Agricultural Research Council Onderstepoort Veterinary Institute, Private Bag X05, Onderstepoort, 0110, Pretoria, South Africa

*Corresponding author: Email: hasscha@yahoo.com (H. Chaka); Tel +251 113380894 Fax +251 113 380220 
Abstract Cross-sectional surveys for Newcastle disease (ND) were conducted in non-vaccinated household flocks of village chickens to assess the serological and virological ND status in households and associated live bird markets. In total 1899 sera and 460 pools of cloacal and tracheal swabs were sampled and tested using a commercial enzyme-linked immunosorbent assay (ELISA) and real time reverse transcriptase polymerase chain reaction (rRT-PCR), respectively. Additionally, paired cloacal and tracheal swabs from 1269 individual chickens were collected from markets and tested using RT-PCR. The prevalence of households with at least one seropositive chicken was higher during the dry season (27.4\%) than during the wet season $(17.4 \%)(P=0.003)$. Viral genome was detected in $14.2 \%$ of households during the wet season using a fusion (F) gene assay and in $23.5 \%$ of households during the dry season using a polymerase (L) gene assay that targets both class I and class II viruses. At the markets sampled overall bird level prevalence was $4.9 \%$ for period 1 (F gene assay), and $38.2 \%$ and $27.6 \%$ for periods 2 and 3, respectively (L gene assay). Partial sequencing of the F gene (239 bp) cleavage site indicated that the majority of the circulating strains exhibited motifs specific to virulent strains. Seroepidemiology coupled with molecular analysis can be a useful tool to assess the status of NDV infection. The village chicken population in Ethiopia is endemically infected with virulent NDV that pose a significant threat to emerging small and medium scale commercial poultry production.

Key words Newcastle disease; village chickens; ELISA; rRT-PCR; Ethiopia 


\section{Introduction}

Newcastle disease (ND) is caused by avian paramyxovirus serotype 1 (APMV-1) belonging to the family Paramyxoviridae, genus Avulavirus (Mayo, 2002). Newcastle disease virus (NDV) can be categorized into highly pathogenic (velogenic), intermediate (mesogenic), and lesspathogenic (lentogenic) strains based on pathogenicity in chickens, and are divided in two clades (class I and class II) (Czegledi et al., 2006). Class I contains almost exclusively low virulence strains recovered from wild waterfowl worldwide. Class II includes strains of low and high virulence isolated from poultry and wild birds. The disease is endemic in the village poultry population in Africa (Bell et al., 1990; Echeonwu et al, 1993; Awan et al., 1994; Chrysostome et al., 1995; Orjaka et al., 1999; Abolnik et al., 2004; Otim et al., 2004; Zeleke et al., 2005; Snoeck et al., 2009; Servan de Almeida et al., 2009, Cattoli et al., 2010, Rasamoelina Andriamanivo et al., 2012) and is regarded as the most important constraint to the development, survival and productivity of village chicken flocks (Alexander et al., 2004; Alder, 2009).

Newcastle disease was first reported in 1971 from a small poultry farm in Asmara, then part of Ethiopia (Bawek et al., 1991), and since then has been considered the most devastating problem of chickens. From the limited reports to the World Organisation for Animal Health (OIE) it also appears the most important poultry disease in Ethiopia, recurring every year (http://web.oie.int/wahis/public.php). However, published information, either serological or virological, on ND epidemiology in Ethiopia is limited. A few cross-sectional studies in backyard chickens have showed that the disease is present with reported individual seroprevalences ranging from $5.6 \%$ to $38 \%$ (Zeleke et al., 2005; Tadesse, et al., 2005; Getachew, 2009; Chaka, et al., 2012). Epidemiological and molecular investigation to understand the NDV status of backyard chickens has never been done in Ethiopia. Molecular 
analysis, along with further characterisation of NDV field isolates, would be useful in order to know the type of strains circulating in a particular geographical area. Reverse transcriptase polymerase chain reaction (RT-PCR) is a useful tool to achieve that without propagation in embryonated eggs (Singh et al., 2005), allowing subsequent sequencing of the amplified DNA and pathotyping even if the virus is found in minute quantities or has lost infectivity (Seal et al., 1995; Gohm et al., 2000; Singh et al., 2005). The different pathotypes can be characterized by the amino acid sequence of the cleavage site of the fusion (F) protein (Aldous et al., 2003; de Leeuw et al., 2005).

The objectives of this study were to determine the seroprevalence at household level (using ELISA) and the prevalence of NDV-infected household flocks (using RT-PCR), during both wet and dry seasons. A further objective was to sample selected live bird markets in order to investigate the prevalence of NDV-infected birds using RT-PCR.

\section{Materials and methods}

Study area

Administratively, Ethiopia is divided into regions which are again sub-divided into zones and then into woredas (districts). A woreda is an administrative unit composed of kebeles, each containing several garees (villages). The study was undertaken in the Oromia administrative region, among households in two randomly selected woredas of East Shewa zone, namely Ada'a and Adami Tulu Jido Kombolcha (ATJK) (Figure 1). The East Shewa zone was specifically selected for its poultry and human population density and the presence of wetlands where other complementary studies were also undertaken. Six markets in the selected woredas were also included for molecular investigation: Hidi, Godino, and Bakajo in Ada'a woreda, and 
Adamitulu, Bulbula, and Abosa in ATJK woreda.

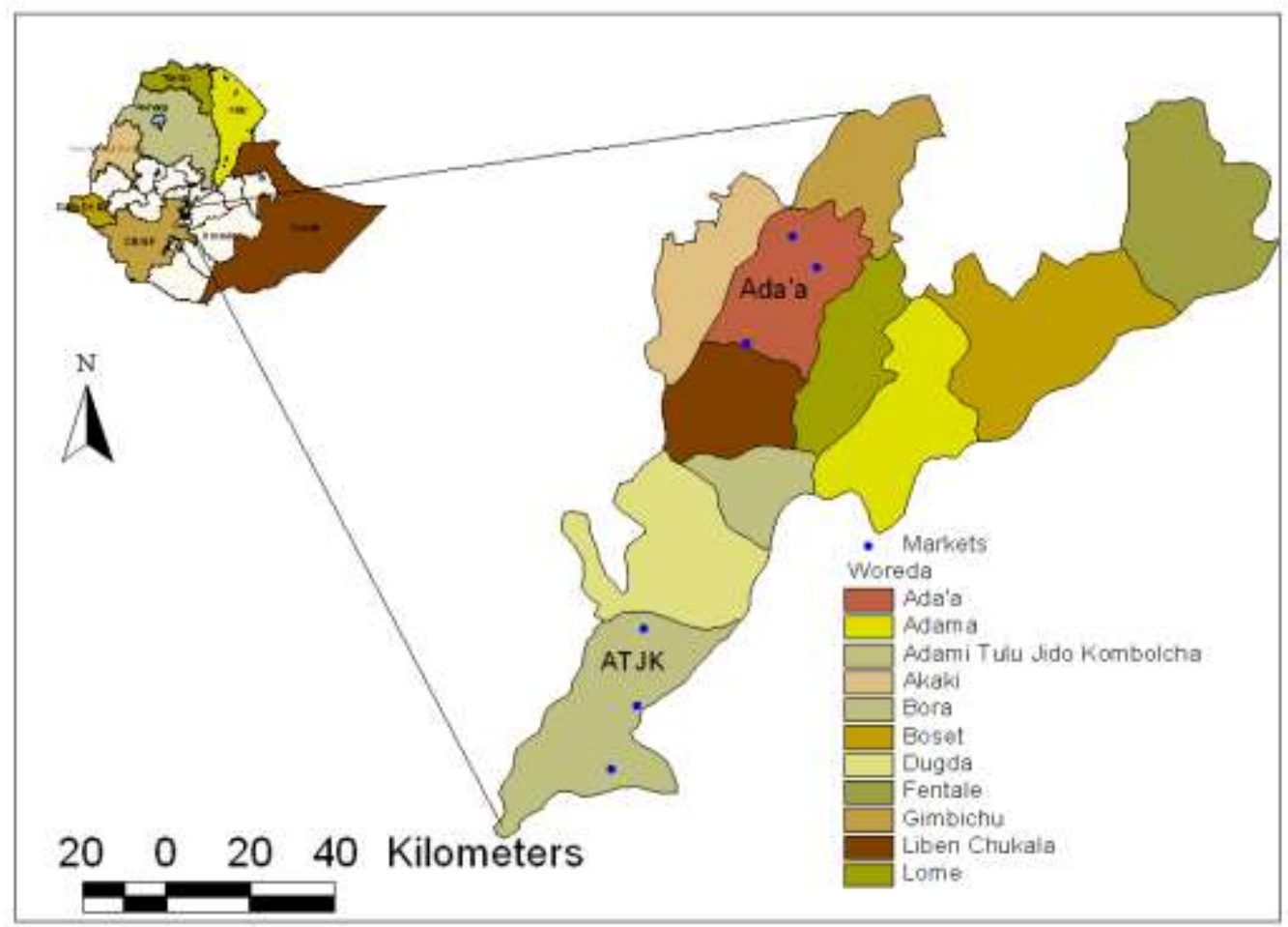

Figure 1: Map of East Shewa zone, Ethiopia indicating the two selected Woredas and markets.

Study design and sample size

A cross-sectional survey was conducted amongst household flocks, with repeated sampling of the same households in September 2009 and May 2010, corresponding to the wet and dry seasons, respectively. The unit of interest was a household flock. The number of households to be sampled was determined at an expected prevalence of $35 \%$, allowable error of $10 \%$ and confidence level of $95 \%$, with a design effect of 3 to account for the multistage survey design (Bennett et al., 1991; Gutierrez-Ruiz, et al., 2000), giving a required sample size of 264 households. First, a list of kebeles in each woreda was compiled and two kebeles were randomly selected from each. In each selected kebele a list of garees was compiled and 12-14 were 
randomly sampled depending on resource availability. Within each garee, five households were randomly selected, provided at least four chickens were present and there was no history of vaccination. From each selected household flock four chickens over 8 weeks old were sampled. During the second survey the same households were sampled; where fewer than four chickens were present, all were sampled. Farmers were also asked whether any new additions of chickens had been made to their flocks from outside sources (either from markets or as a gift) since the first survey, and whether any signs suggestive of ND infection (respiratory distress, diarrhea, ocular and nasal discharge, nervous signs or sudden death) had been noted in their flocks.

The six markets were strategically selected, being markets that served the study woredas, and where birds sold were only from producer-sellers. The number of birds to be sampled in each market was calculated assuming a market size of 50-100 chickens, a minimum expected prevalence of $5 \%$ and a $95 \%$ confidence level. Sellers were selected by convenience sampling and only one bird was swabbed from any individual seller on each occasion. Market sampling was done between June 2009 and August 2010, during three strategically selected sampling periods: periods 1 and 3 representing wet seasons (June-August) and period 2 representing the dry season (March-April).

\section{Sampling procedures}

In household flocks, $1.5 \mathrm{ml}$ of blood was drawn from the brachial vein in a $3 \mathrm{ml}$ disposable syringe, using a new syringe and needle for each chicken. Blood was allowed to clot and was kept at room temperature for serum collection. A total of 1018 and 881 sera from 260 and 249 households were collected during the wet and dry seasons, respectively. For molecular investigation, tracheal swabs and cloacal swabs collected from all selected chickens in each 
household were pooled separately in viral transport media containing streptomycin sulphate, penicillin and mycostatin in phosphate buffer solution, resulting in 460 separate pools of each. At the markets, tracheal and cloacal swabs were collected separately from individual chickens, resulting in 1269 pairs of swabs in total.

Serological testing

Enzyme-linked immunosorbent assays (ELISA) on chicken sera were performed at the National Animal Health Diagnostic and Investigation Center (NAHDIC), Sebata, Ethiopia, using a commercial blocking ELISA kit (Svanovir NDV-Ab, SVANOVA Biotech, Uppsala, Sweden) to detect specific antibodies against APMV-1 (Czifra, 1996; Gohm et al., 1999) according to the manufacturer's instructions. The sample and control optical density (OD) values were read using an ELISA reader (Immunoscan, BDSL) at $450 \mathrm{~nm}$. The percentage inhibition (PI) was calculated from OD values according to the following formula:

$$
\mathrm{PI}=\left[\left(\mathrm{OD}_{\text {Negative control }}-\mathrm{OD}_{\text {Sample }}\right) / \mathrm{OD}_{\text {Positive control }}\right] \times 100 / \mathrm{OD}_{\text {Negative Control }}
$$

A household was classified as positive if one or more chickens in the flock tested positive, with PI $>40$.

RNA extraction and RT-PCR assay

Real time (r) RT-PCR assays were performed at the Centre de Coopération Internationale en Recherche Agronomique pour le Développement (CIRAD), Montpellier, France and at the Agricultural Research Council - Onderstepoort Veterinary Institute (ARC-OVI), Pretoria, South Africa. The swab samples from the first household survey and the first market survey were tested at CIRAD to detect the NDV genome-specific fusion (F) gene cleavage site sequence. Viral 
RNA was extracted on a high throughput automated workstation Biomek FX ${ }^{\mathrm{P}}$ (Beckman) using the Nucleospin RNA virus kit (Macherey Nagel). NDV was detected on the F gene by one step rRT-PCR method using a Stratagene Machine Mx3000 or 3005. Additionally, on the positive swab samples, the coding region of the F gene (239 bp), including the cleavage site, was amplified and directly sequenced to determine the pathotype and to perform a phylogenetic study. Swab samples from the second household survey and the second and third market surveys were tested at ARC-OVI. RNA was extracted using a Total Nucleic Acid extraction kit (Roche) on a MagnaPure robotic system (Roche), or using TriZol reagent (Invitrogen), according to the recommended procedure. The rRT-PCR method described by Fuller et al. (2010) was followed, using an LC480 thermocycler (Roche). Since this assay targets the polymerase (L) gene and thus detects broad spectrum of APMV-1 (both class I and II viruses), 36 samples that tested NDV positive based on the $\mathrm{L}$ gene target were re-tested at ARC-OVI on an LC480 thermocycler (Roche) using the assay described by Wise et al. (2004) that targets a conserved region of the matrix (M) gene and detects only class II viruses. A household or bird was classified as positive if virus RNA was detected in either cloacal or tracheal swabs.

\section{Data analysis}

Data were managed in Microsoft Excel and analysed using STATA 11.1 (Stata Corp, College Station, TX, USA). In all analyses two-tailed tests and a significance level of 5\% were used. Estimates of the household-level seroprevalence of ND and viral genome prevalence, with $95 \%$ confidence intervals (CI), were calculated by season, woreda and kebele, adjusting for sampling weights in the multistage survey design. Prevalence was compared between woredas and kebeles using the Pearson chi-square statistic which was corrected for the survey design with the secondorder correction of Rao and Scott (1984). A hierarchical mixed-effects logistic regression model, 
with kebele and village as random effects, was used to compare the odds of seropositivity between seasons. The association between seropositivity and rRT-PCR at the household level was assessed using odds ratios and the Fisher's exact test for each of the two sampling times, and agreement between the two tests was assessed using the kappa statistic. The prevalence of NDV genome detection in market samples was calculated with binomial exact 95\% CI. The molecular results were not comparable between seasons because of the different assays employed.

\section{Results}

Overall, 1899 chicken sera (1018 and 881 during the wet and dry seasons, respectively) and 460 pairs of pooled swabs (243 and 217 during the wet and dry seasons, respectively) were tested in the household surveys. Fewer samples were collected during the second sampling, mainly because 11 households no longer had any chickens present and in $24.1 \%(60 / 249)$ of the households fewer than four chickens were present. At the first sampling, flock size (excluding small chicks) ranged from 4 to 28 (median: 7; interquartile range (IQR): 5-10). At the second sampling, excluding households that had no chickens, flock size ranged from 1 to 36 (median: 6; IQR: 4-10). Of the 70 households that contained seropositive birds during the second sampling, $75.1 \%(53 / 70)$ had reduced flock size. Of all the households, 55.8\% (145/260) experienced reduced flock size, with loss due to disease claimed by owners in $71.7 \%(104 / 145)$ of these, while in 34.6\% (90/260) of all households the farmers claimed to have had ND in their flocks in the period between the two surveys. Of the households where farmers reported chicken losses in their flocks, $60.5 \%(141 / 233)$ attributed it to disease, $15.5 \%$ (36/233) to predators, $4 \%(10 / 233)$ to climatic stress, $3.4 \%(8 / 233)$ to accidents and $16.3 \%$ (40/233) to a combination of these causes. Additionally, off-take due to market selling was reported in $90.4 \%(235 / 260)$ of the households. 
ELISA PI values $\geq 60$ were recorded in $80.4 \%$ (45/56) and $78.1 \%$ (75/96) of all seropositive chickens in $82.6 \%(38 / 46)$ and $78.6 \%(55 / 70)$ of seropositive households during the wet and dry season, respectively. In the market surveys a smaller number of swabs than expected were collected for some of the markets because very few chickens were present on the day of the visit. All farmers reported that their chickens had never been vaccinated.

Table 1 shows the household-level seroprevalence of ND by woreda and kebele in the study area during the wet and dry seasons, adjusted for sampling weights. The prevalence of households with at least one seropositive bird was estimated to be $17.4 \%$ (95\% CI: $7.8-34.2 \%$ ) and $27.4 \%$ (95\% CI: $14.3-46.1 \%$ ) during the wet and dry seasons, respectively; this difference was statistically significant $(\mathrm{OR}=2.03,95 \% \mathrm{CI}: 1.3-3.2, P=0.003)$. During the wet season the household level seroprevalence was somewhat higher in Ada'a (20\%) than in ATJK (15\%) and

Table 1: Newcastle disease household flock seroprevalence during September 2009 (wet season) and May 2010 (dry season) in backyard chicken flocks in Eastern Shewa zone, Ethiopia.

\begin{tabular}{rllllll}
\hline \multirow{2}{*}{$\begin{array}{c}\text { Woreda/ } \\
\text { Kebele }\end{array}$} & $\mathrm{n}^{\mathrm{a}}$ & \% pos (95\% CI) & $P$-value & $\mathrm{n}^{\mathrm{a}}$ & $\%$ pos (95\% CI) & $P$-value \\
\hline ATJK woreda & 130 & $15.2(3.4-47.5)$ & 0.48 (woredas) & 127 & $21.5(7.1-49.5)$ & 0.16 (woredas) \\
Negalign & 60 & $22.3(17.7-27.7)$ & 0.08 (kebeles) & 59 & $28.8(22.8-35.6)$ & 0.09 (kebeles) \\
D/Abyata & 70 & $11.5(8.4-15.4)$ & & 68 & $17.6(14-21.9)$ & \\
Ada'a woreda & 130 & $20.0(15.0-26.0)$ & & 122 & $34.5(27.6-42)$ & \\
GGorba & 70 & $20.0(14.2-28.3)$ & 0.81 (kebeles) & 65 & $35.6(28-43.9)$ & 0.55 (kebeles) \\
Ude & 60 & $17.4(7.8-34)$ & & 57 & $33.3(14.3-41.6)$ & \\
Overall & 260 & $17.4(7.8-34.2)$ & & 249 & $27.4(14.3-46.1)$ & \\
\hline${ }^{a}$ number of household flocks & & & & &
\end{tabular}


varied from $11.5 \%$ to $22.3 \%$ among kebeles, although these differences were not statistically significant. Similarly, during the dry season the seroprevalence was relatively higher in Ada'a (34\%) than in ATJK (21\%) and varied from $17.6 \%$ to $33.3 \%$ among kebeles. Of the 70 households that contained seropositive birds during the dry season, 70\% (49/70) had previously tested negative during the wet season, indicating new infections and seroconversion.

Table 2 shows the rRT-PCR analysis results from the pooled swabs from household flocks. In the wet season, using the F gene assay, 14.2\% (34/243) of households tested positive. In the dry season, using the L gene assay, 24.2\% (51/217) tested positive. During the wet season the rRT-PCR prevalence was slightly higher in Ada'a woreda (18.7\%) than in ATJK (9.3\%) and a relatively higher prevalence was also observed in Ada'a during the dry season. However, these differences were not significant (Table 2).

Table 2: Newcastle disease virus detection by molecular assays in household flocks during September 2009 (wet season) and May 2010 (dry season) in backyard chicken flocks in Eastern Shewa zone, Ethiopia.

\begin{tabular}{rllllll}
\hline Woreda/ & \multicolumn{5}{l}{ Wet season $^{\mathrm{a}}$} \\
\cline { 2 - 6 } Kebele & $\mathrm{n}$ & $\%$ pos $(95 \% \mathrm{CI})$ & $P$-value & $\mathrm{n}$ & $\%$ pos (95\% CI) & $P$-value \\
\hline ATJK woreda & 118 & $9.9(2.7-30.5)$ & 0.39 (woredas) & 127 & $20.41(7.7-44.1)$ & 0.43 (woredas) \\
Negalign & 60 & $6.3(4.5-9.6)$ & 0.12 (kebeles) & 59 & $14.3(1.1-18.7)$ & 0.10 (kebeles) \\
D/Abyata & 58 & $12.3(8.6-17.3)$ & & 68 & $23.7(18.9-29.2)$ & \\
Ada'a woreda & 125 & $18.7(1.7-75.1)$ & & 90 & $30.5(5.0-78.5)$ & \\
GGorba & 65 & $9.3(5.9-14.4)$ & 0.07 (kebeles) & 65 & $22.8(17.0-29.7)$ & 0.08 (kebeles) \\
Ude & 60 & $28.1(21.2-36.2)$ & & 25 & $48.1(35.2-61.3)$ & \\
Total & 243 & $14.2(3.2-45.2)$ & & 217 & $24.2(12.0-42.8)$ &
\end{tabular}

\footnotetext{
${ }^{\mathrm{a}} \mathrm{F}$ gene assay for class I NDV

${ }^{\mathrm{b}}$ L gene assay for class I and II NDV (Fuller et al., 2010)
} 
Table 3 shows the cross tabulation between household seropositivity and rRT-PCR result. There was a weak association during the wet season $(\mathrm{OR}=2.14 ; 95 \% \mathrm{CI}: 0.94,4.89 ; P=0.09)$ but not during the dry season $(\mathrm{OR}=1.27 ; 95 \% \mathrm{CI}: 0.63,2.55 ; P=0.58)$. The kappa statistic for agreement between the ELISA and the rRT-PCR was 0.12 and 0.05 during the wet and dry seasons, respectively, both of which can be considered as only slight agreement. In 77\% (34/44) and $73 \%$ (41/56) of households which were seropositive by ELISA, during wet and dry seasons respectively, NDV genome was not detected by rRT-PCR. Seventy two per cent (175/243) and $57.6 \%(125 / 217)$ of households tested had neither detectable antibodies nor viral genome in their samples during wet and dry seasons, respectively.

Table 3 Associations between Newcastle disease serology and virus detection by molecular assays during September 2009 (wet season) and May 2010 (dry season) in backyard chicken flocks in Eastern Shewa zone, Ethiopia.

\begin{tabular}{|c|c|c|c|c|c|c|c|}
\hline & & \multicolumn{6}{|c|}{ Household rRT-PCR result } \\
\hline & & \multicolumn{3}{|c|}{ Wet Season $^{\mathrm{a}}$} & \multicolumn{3}{|l|}{ Dry season $^{b}$} \\
\hline & & Pos & $\mathrm{Neg}$ & Total & Pos & Neg & Total \\
\hline & Pos & $10(4.1)^{\mathrm{c}}$ & $34(14.0)$ & 46 & $15(6.9)$ & $41(18.9)$ & 56 \\
\hline Household & $\mathrm{Neg}$ & $24(9.9)$ & $175(72.0)$ & 199 & $36(16.6)$ & $125(57.6)$ & 161 \\
\hline serology & Total & 34 & 209 & 243 & 51 & 166 & 217 \\
\hline \multicolumn{2}{|c|}{ OR $(95 \% \mathrm{CI})$} & \multicolumn{3}{|c|}{$2.14(0.94-4.89)$} & \multicolumn{3}{|c|}{$1.27(0.63-2.55)$} \\
\hline \multicolumn{2}{|l|}{$P$-value } & \multicolumn{3}{|l|}{0.09} & \multicolumn{3}{|l|}{0.58} \\
\hline \multicolumn{8}{|c|}{${ }^{\mathrm{a}} \mathrm{F}$ gene assay for class I NDV } \\
\hline \multicolumn{8}{|c|}{${ }^{\mathrm{b}} \mathrm{L}$ gene assay for class I and II NDV (Fuller et al., 2010) } \\
\hline
\end{tabular}


Table 4: Bird-level prevalence of NDV genome at live bird markets in Eastern Shewa zone, Ethiopia between June 2009 and August 2010.

\begin{tabular}{|c|c|c|c|c|c|c|c|c|c|}
\hline \multirow{3}{*}{$\begin{array}{l}\text { Woreda/ } \\
\text { Market }\end{array}$} & \multicolumn{3}{|c|}{ Period 1 (June-August 2009) } & \multicolumn{3}{|c|}{ Period 2 (March-April 2010) } & \multicolumn{3}{|c|}{ Period 3 (July-August 2010) } \\
\hline & $\mathrm{n}^{1}$ & $\% \operatorname{pos}(95 \% \mathrm{CI})$ & $P-$ & $\mathrm{n}^{1}$ & $\% \operatorname{pos}(95 \% \mathrm{CI})$ & $P-$ & $\mathrm{n}^{1}$ & $\% \operatorname{pos}(95 \% \mathrm{CI})$ & $P-$ \\
\hline & & & value & & & value & & & value \\
\hline Ada'a woreda & 282 & $5.3(3.0 ; 8.6)^{\mathrm{A}}$ & 0.72 & 83 & $28.9(19.5 ; 39.9)^{\mathrm{A}}$ & 0.04 & 87 & $33.3(23.6 ; 44.3)^{\mathrm{A}}$ & 0.15 \\
\hline Hidi & 107 & $1.9(0.2 ; 6.6)$ & 0.09 & 15 & $20.0(4.3 ; 48.1)$ & 0.5 & 22 & $36.4(17.2 ; 59.3)$ & 0.92 \\
\hline Godino & 25 & $4.0(0.1 ; 2.0)$ & & 16 & $37.5(15.2 ; 64.6)$ & & 7 & $28.6(3.7-70.0)$ & \\
\hline Bakajo & 150 & $8.0(4.2 ; 13.6)$ & & 52 & $28.8(17.1 ; 43.1)$ & & 58 & $32.7(21.0 ; 46.3)$ & \\
\hline ATJK woreda & 440 & $4.5(2.8 ; 6.9)^{\mathrm{A}}$ & & 192 & $42.2(35.1 ; 49.5)^{\mathrm{B}}$ & & 185 & $24.9(18.8 ; 31.7)^{\mathrm{A}}$ & \\
\hline A/Tulu & 150 & $2.0(0.4 ; 5.7)$ & 0.04 & 70 & $38.6(27.1 ; 51.0)$ & 0.1 & 65 & $23.1(13.5 ; 35.2)$ & 0.2 \\
\hline Bulbula & 150 & $8.0(4.2 ; 13.6)$ & & 73 & $37.0(26.0 ; 49.1)$ & & 70 & $20.0(11.4 ; 31.3)$ & \\
\hline Abosa & 140 & $3.5(1.2 ; 8.1)$ & & 49 & $55.1(40.0 ; 69.3)$ & & 50 & $34.0(21.2 ; 48.8)$ & \\
\hline Total & 722 & $4.9(3.4 ; 6.7)$ & & 275 & $38.2(32.4 ; 44.2)$ & & 272 & $27.6(31.3 ; 45.4)$ & \\
\hline
\end{tabular}

${ }^{1}$ number of chickens

${ }^{\mathrm{A}, \mathrm{B}}$ Woredas with different superscripts differ significantly $(\mathrm{P}<0.05)$

Table 4 shows the molecular detection of NDV in cloacal and tracheal swabs sampled at markets during three different periods, between June 2009 and August 2010. The overall birdlevel prevalence of class II NDV genome (F gene assay) during period 1 was 4.9\%. Using the $\mathrm{L}$ gene based assay that detects both classes of APMV-1 it was 38.2\% and 27.6\%, for periods 2 and 3 , respectively. A weakly significant difference $(P=0.04)$ between woredas was only noted during period 2 (dry season), when the prevalence was higher in ATJK (42.2\%) than in Ada'a (28.9\%). There was no significant variation among markets within a woreda in any of the period except for markets in ATJK during period 1. Upon further analysis of 36 swabs from households 
and markets that were positive for the L gene assay (Fuller et al., 2010), only 14 (39\%) were positive by the M gene assay that detects only class II NDV (Wise et al., 2004).

On direct sequencing of partial F gene (239 bp) in rRT-PCR positive samples, the cleavage site showed amino acid motifs typical of velogenic strains (“G/RRQKR/FV”, "G/RRRKR/FV”, or "G/KRRKR/FV"). Preliminary results of phylogenetic analysis based on F gene sequences of 180 nucleotides detected in market and village samples revealed that the virus strains fell in clusters within genotypes VI and VII. A few samples showed amino acid motifs characteristic of avirulent strains (“G/GRQGR/LI”, “G/GKQGR/LI”) from genotypes I and II of class II viruses. A complementary study involving detailed characterization by sequence analysis, of the virus isolates obtained at markets and households in the study area will be published elsewhere.

\section{Discussion}

In this study we have detected changes in ND seroprevalence in household poultry flocks over time thus indicating ongoing exposure to NDV and incidence of the disease. The overall household level seroprevalence (proportion of household with at least one seropositive bird) was $17.4 \%$ and $27.4 \%$ during the wet and dry seasons, respectively, and was significantly higher during the dry season $(P=0.003)$. During the second survey, corresponding to the dry season, fewer birds per household were found, indicating that households had lost their chickens, possibly due to incidence of the disease in their flocks, amongst other factors. This was corroborated in many cases by the farmer's report of clinical ND in their flocks, and $75.1 \%$ (53/70) of households seropositive during the second sampling had reduced flock sizes. Chicken off-take due to market selling, reported in $90.4 \%$ (235/260) of the households, also contributed to reduced flock size. In Nigeria, high seroprevalence has been demonstrated during November to 
March (dry season) indicating that more outbreaks occurred during that time of the year (Orajaka et al., 1999; Musa et al., 2009). Within seasons, although there was no significant difference in household-level seropositivity between woredas, variation was observed among kebeles. This could indicate that, although the disease is ubiquitous, the epidemiology and ecology of NDV varies locally in terms of stages of epidemic cycle, where certain areas could be in an interepidemic period, having low virus activity, while others are in early infection or experiencing an active outbreak. Such phenomena, along with change in the village poultry population, with variable immune status, probably maintain NDV circulation throughout the year in backyard chickens.

Our estimates for flock seroprevalence were comparable to the $15.9 \%$ (range 11.3-23.0\%) reported from East Timor (Serrão et al., 2012), although a much higher flock seroprevalence (89\%) was recorded in chickens of smallholdings in Bangladesh (Biswas et al., 2009). The principal limitation in comparing the present finding with previous serological studies either in Ethiopia or elsewhere was that they mostly assessed individual bird antibody prevalence. In addition, most previous studies have employed haemagglutination inhibition (HI) tests with various cut-off values (Kelly et al., 1994; Chrystome et al., 1995; Idi et al., 1999; Tadesse, et al., 2005; Musa et al., 2009). Variations in prevalence could also be attributed to ecological characteristics of a specific area, such as climate, settlement pattern, sanitary and socio-economic practices, which may facilitate disease spread, and also the season in which the study was done.

The ELISA PI values equal to or greater than 60 recorded in a high proportion of all seropositive chickens during both the wet season (82.6\%) and the dry season $(78.6 \%)$ in our study may suggest recent field exposure to virulent NDV strains (Chrysostome et al., 1995; Alexander et al., 2004;). Velogenic strains of the virus are known to produce higher antibody 
titres than lentogenic and mesogenic strains (Luc et al., 1992; Alexander et al., 2004). Sequencing of the fusion protein cleavage site of rRT-PCR-positive household and market samples confirmed the circulation of virus strains bearing amino acid motifs "G/RRQKR/FV" or "G/RRRKR/FV", characteristic of virulent viruses (Lamb et al., 2007, OIE, 2008). Since chickens had not been vaccinated, these were likely the strains causing most of the seroconversion in our study area, although the circulation of some avirulent strains from genotypes I and II, found in a few of our samples, may have contributed to this. It has previously been reported that velogenic NDV strains are common in village situations (Martin, 1992). Bell and Mouloudi (1988) observed that velogenic virus strains were common in village chickens in Morocco, and virulent strains were also observed in apparently healthy chickens in Mali and Madagascar based on rRT-PCR analysis (Servan de Almeida et al., 2009). Given that the chickens sampled in the present surveys were apparently healthy yet infected with virulent strains of NDV, this may suggest the possibility of carrier birds amongst the village chickens in Ethiopia. Such a phenomenon has been described by Awan et al. (1994) and has considerable implications in the epidemiology of the disease. Another interesting possibility is that circulating avirulent strains may be causing seroconversion and providing some degree of protection against virulent NDV, as has previously been reported (Turner et al., 1976; Spradbrow, et al., 1980; Samuel and Spradbrow, 1989). It is also possible that some birds were sampled during the early stage of infection before any evident clinical signs of the disease.

Seropositivity was not highly correlated with virus RNA detection at household level, and agreement between the ELISA and rRT-PCR was poor, as revealed by very low kappa values. This could indicate that virus circulation is enhanced when the level of antibody wanes or the number of susceptible chickens in a flock increases. The presence or absence of detectable 
antibody levels within a flock depends also on the phase of infection at the time of sampling. Bell and Mouloudi (1988) in Morocco obtained more viruses from areas with lower antibody levels. In general, Ada'a woreda had the highest prevalence of NDV genome at household level during both seasons but with considerable variation, within woreda, among kebeles in the study area (Table 2). The reason for such variation, as for seroprevalence, may be due to local variation in the stages of the epidemic cycle, but variation in ecology between areas that can affect virus viability in the environment may also play a role (Orajaka et al., 1999). From our field observations we also noted that households within villages in ATJK woreda were more scattered than those in Ada'a, which may have reduced the chance of contact transmission between household flocks during scavenging.

The molecular techniques employed for NDV detection varied between the two surveys; the L gene assay that detects viruses of all the genetic lineages in classes I and II showed a greater proportion of positives compared to the F gene-based assay that detects only class II viruses, and attributed as the potential causes for the such observed variations in proportions between surveys. This was further confirmed on the re-testing of a subset of the L gene-positive samples from the dry season at households and markets, where only about $39 \%$ of them were attributable to class II NDV. However, it is also possible that RNA degradation may also have contributed to the lower proportion of positive samples upon repeated testing; therefore it is not possible to compare the estimated prevalences between the two surveys. Viral circulation may vary depending on factors that could increase the number of susceptible birds and predispose to outbreaks. These include a seasonal peak in hatching generally observed during the dry season in Ethiopia resulting from farmers' avoidance of wet season hatching with associated chick losses due to cold stress, as well as movements due to marketing practices. Increased movement of live 
birds during festivals, in anticipation of good prices, could increase the incidence of outbreaks (Sa'idu, et al., 2006; Newanta, et al., 2006). In the market surveys, a higher prevalence of NDV genome was detected during period 2 (dry season), which coincided with the Ethiopian Easter holiday in April, than during period 3 (wet season). In a survey targeting virus isolation at markets (unpublished data), we also found more sick chickens and correspondingly more virus isolates, from sampling done during the dry season. This might be associated with poultry movements related with the Ethiopian Easter holiday that could facilitate disease spread. Orajaka et al. (1999) also noted more intense NDV activity during the cold dry period (Harmattan) in Nigeria, possibly associated with cold and windy weather or market-related poultry movements. Nevertheless, the proportion of virus genome detection might not necessarily indicate the actual infection status of household chickens as NDV neutralized by antibodies, i.e. non infectious genome, may be detected by RT-PCR for a relatively long period after infection (Westbury et al., 1984; Gohm, et al., 2000, Fuller et al., 2010).

The lack of detectable antibodies to NDV or virus genome was noted in a high proportion of household flocks during wet $(72.0 \%)$ and dry (57.6\%) seasons, indicating that significant numbers of the village chickens are highly susceptible should virulent NDV infection occur (Allan and Gough,1974), as ND is highly transmissible in such flocks (van Boven et al., 2008). Henning et al. (2008) observed higher mortality rates in villages that had low proportions of birds with protective serological titres in Myanmar.

This study indicated the possible presence of class I viruses in backyard chickens of Ethiopia. This class is regarded as avirulent in chickens and has been recovered from waterfowl and shorebirds and also frequently from live bird markets elsewhere (Kim et al., 2007). The role of this class of virus in the epidemiology of ND is not clear for the moment and needs to be 
assessed. The presence of mild virus strains may contribute silently to increased antibody titres without visible clinical signs in infected chickens (Kite et al., 2007).

In the partial $\mathrm{F}$ gene (239 bp) sequence analysis and sequence alignment the virus from markets and village samples grouped in similar clusters, which suggests that the same virus strains were circulating between markets and villages. However, this needs further investigation. During the study we also investigated an outbreak of disease in wild doves (Streptopelia spp.) in a village setting, which was diagnosed using a molecular test as caused by pigeon PMV-1. Investigations to understand the epidemiological links between wild bird isolates and those recovered from domestic poultry are continuing.

In conclusion, sero-epidemiology coupled with molecular analysis can be a useful tool to assess the status of NDV infection in an area and provide insights for further investigations. Our survey results showed that the village household chicken population is endemically infected with NDV, with a high proportion of household flocks experiencing new infections. Several circulating virus strains are believed to be the causes for the periodic outbreaks of the disease, with a tendency towards higher incidence during the dry season. This may also hold true for many other parts of Africa, or elsewhere in the world, where similar agro-ecological conditions exist. The presence of such virulent strains of NDV in household chickens could pose a significant threat to the development of the emerging small and medium commercial poultry production sector in Ethiopia. To reduce the seasonal mortality of the disease, vaccination at household level could be considered with due attention to its sustainability. In addition, further study is warranted to better understand the epidemiology of the disease and to characterize virus strains circulating in the study area, including the class I viruses, in order to properly aid control of ND. 


\section{Acknowledgments}

The study was done under the framework of the GRIPAVI research project, funded by the French Ministry of Foreign and European Affairs (MAEE). Authors would like to thank staff members at NAHDIC for assistance during fieldwork, and members of CIRAD and ARC-OVI (Marco Romito, Thandeka Phiri, Bontsi Moshotlhoane) for laboratory analysis. The authors are very grateful to the flock owners, field veterinary staff and development agents who facilitated the fieldwork.

\section{Conflict of interest statement}

The authors declare that they have no conflict of interest.

\section{References}

Abolink, C., Horner, R.F., Bisschop, S.P., Parker, M.E., Romito, M. and Viljoen, G.J., 2004. A phylogenetic study of South African Newcastle disease virus strains isolated between 1990 and 2002 suggests epidemiological origin in the Far East, Archives of Virology, 149, 603619.

Alder, R., 2009. Newcastle disease overview in Africa. Workshop on Newcastle disease and vaccine, Maputo, Mozambique. October, 5-9, 2009. (available at http://www.galvmed.org/news-resources/content/workshop-newcastle-disease-and-ndvaccines).

Aldous, E.W., Mynn, J.K., Banks, J. and Alexander, D.J., 2003. A molecular epidemiological study of avian paramyxovirus type 1 (Newcastle disease virus) isolates by phylogenetic 
analysis of a partial nucleotide sequence of the fusion protein gene, Avian Pathology, 32, 239-256.

Alexander, D.J., Bell, J.G. and Alders, R.G., 2004. A technology review, Newcastle disease. Animal production and health book, 161, (Food and Agricultural Organization, Rome).

Allan, W.H. and Gough, R.E., 1974. A standard haemagglutination inhibition test for Newcastle disease. A comparison of macro and micro methods, Veterinary Record, 95, 120-123.

Awan, M.A., Otte, M.J. and James, A.D., 1994. The epidemiology of Newcastle disease in rural poultry: a review, Avian Pathology, 23, 405-423.

Bawek, L., Naser, M., Berhanu, A., and Mengistu, A., 1991. Newcastle disease in Ethiopia. In Rweyemamu M.M, Palya V., and Win, T.(Eds), Newcastle disease vaccines in rural Africa, Proceeding of a workshop held at Pan African Veterinary Vaccine Centre, Debre Zeit, Ethiopia. 22-26 April, 1991. Pp49-51.

Bell, J.G., Kane, M. and Lejan, C., 1990. An investigation of the disease status of village poultry in Mauritania, Preventive Veterinary Medicine, 8, 291-294.

Bell, J.G. and Mouloudi, S., 1988. A reservoir of virulent Newcastle disease virus in village chicken flocks, Preventive Veterinary Medicine, 6, 37-42.

Bennett, S., Woods, T., Liyanage, W.M., Smith, D.L., 1991. A simplified general method for cluster-sample surveys of health in developing countries. World Health Statistics Quarterly, 44, 98-106.

Biswas, P.K., Barua, H., Uddin, G.M.N., Biswas, D., Ahad, A. and Debnath, N.C., 2009. Serosurvey of five viruses in chickens on smallholdings in Bangladesh, Preventive Veterinary Medicine, 88, 67-71. 
Cattoli, G., Fusaro, A., Monne, I., Molia, S., Le Menach, A. , Maregeya, B., Nchare, A., Bangana, I., Garba Maina A., N’Goran Koffi, J.N., Thiam, H., Bezeid, O.E., Salviato, A. , Nisi, R., Terregino, C. and Capua, I., 2010. Emergence of a new genetic lineage of Newcastle disease virus in West and Central Africa-Implications for diagnosis and control, Veterinary Microbiology, 142, 168-176.

Chaka ,H., Goutard, F., Bisschop, P.R. and Thompson, P.N., 2012. Seroprevalence of Newcastle disease and other infectious disease in backyard chickens at markets in Eastern Shewa zone, Ethiopia, Poultry Science, 91, 862-869.

Chrysostome, C.A., Bell, J.G., Demey, F. and Verhulst, A., 1995. Seroprevalences to three diseases in village chickens in Benin, Preventive Veterinary Medicine, 22, 257-261.

Czegledi, A., Ujvari, D, Somogyi, E., Wehmann, E., Werner, O. and Lomniczi, B., 2006. Third genome size category of avian paramyxovirus serotype 1 (Newcastle disease virus) and evolutionary implications, Virus Research, 120, 36-48.

Czifra, G., Nilsson, M., Alexander, D. J., Manvell, R., Kecskeméti, S. and Engström, B. E., 1996. Detection of PMV-1 specific antibodies with a monoclonal antibody blocking enzyme-linked immunosorbent assay, Avian Pathology, 25, 691-703.

De Leeuw, O.S., Koch, G., Hartog, L., Ravenshorst, N. and Peeters, B.P., 2005. Virulence of Newcastle disease virus is determined by the cleavage site of the fusion protein and by both the stem region and globular head of the haemagglutinin-neuraminidase protein, Journal of General Virology, 86, 1759-1769.

Echeonwu, G.O.N., Iroegbu, G.U. and Emeruwa, A.C., 1993. Recovery of Velogenic Newcastle disease virus from dead and healthy free-roaming birds in Nigeria, Avian Pathology, 22, $383-387$. 
Fuller, C.M., Brodd, L., Irvine, R. M, Alexander, D. J. and Aldous, E. W., 2010. Development of an L gene real-time reverse-transcription PCR assay for the detection of avian paramyxovirus type 1 RNA in clinical samples, Archive of virology, 155, 817-823.

Getachew, B., 2009. Isolation, identification and Seroprevalence of Newcastle disease virus in village chicken in South West Shewa, Ethiopia, (unpublished MSc Thesis, Addis Ababa University).

Gohm, D.S., Thür, B. and Hofmann, M.A., 2000. Detection of Newcastle disease virus in organs and faeces of experimentally infected chickens using RT-PCR, Avian Pathology, 29, 143152.

Gohm, D.S, Thür, B., AudigeÂA, L. and Hofmann, M. A., 1999. A survey of Newcastle disease in Swiss laying-hen flocks using serological testing and simulation modelling, Preventive Veterinary Medicine, 38, 277-288.

Gutierrez-Ruiz, E.J., Ramirez-Cruz, G.T., Camara Gamboa, E.I., Alexander, D.J. and Gough, R.E., 2000. A Serological Survey for Avian Infectious Bronchitis Virus and Newcastle Disease Virus Antibodies in Backyard (Free- range) Village Chickens in Mexico, Tropical Animal Health and Production, 32, 381-390.

Henning, J., Morton, J., Hla, T. and Meers, J., 2008. Mortality rates adjusted for unobserved deaths and associations with Newcastle disease virus serology among unvaccinated village chickens in Myanmar, Preventive Veterinary Medicine, 85, 241-252.

Idi, A., Maikano, I. and Adamou, H., 1999. Seroprevalence of Newcastle disease and infectious bursal disease in local chickens commercialized in Niamey, Niger. INFPD Newsletter Vol. 9 No. 1, January - March 1999. 
Kelly, P.J., Chitauro, D., Rohde, C., Rukwava, J., Majok, A., Davelaar, F. and Mason, P.R., 1994. Diseases and management of backyard chicken flocks in Chitungwiza, Zimbabwe, Avian Diseases, 38, 626-629.

Kim, L.M., King, D.J., Curry, P.E., Suarez, D.L., Swayne, D.E., Stallknecht, D.E., Slemons, R.D., Pedersen, J.C., Senne, D.A., Winker, K., et al., 2007. Phylogenetic diversity among low virulence Newcastle disease viruses from waterfowl and shorebirds and comparison of genotype distributions to poultry-origin isolates, Journal of Virology, 81, 12641-12653.

Kite, V.G, Boyle, D.B., Heine, H.G., Paitchard, I., Garner M.G. and East I.J., 2007. A serological and virological survey for the evidence of infection with Newcastle disease virus in Australian chicken farms, Australian Veterinary Journal, 85,236-242.

Lamb, R.A. and Jardetzky, T.S., 2007 Structural basis of viral invasion: Lessons from paramyxovirus F, Current Opinion in Structural Biology, 17, 427-436.

Luc, P.V., Hong, N.T. and Chinh, V.T., 1992. Level of anti-Newcastle Disease virus antibodies in industrial poultry at various ages and seasons, Agriculture Food Industry, 9, 348-350.

Martin, P.A.J., 1992. The epidemiology of Newcastle disease in village chickens. In: P.B. Spradbrow (eds) Proceedings international workshop on Newcastle disease in village chickens, 6-10 October 1991; Malaysia, pp 40-45.

Mayo, M.A., 2002. A summary of the changes recently approved by ICTV, Archives of Virology $147,1655-1656$.

Musa, U., Abdu, P. A., Dafwang, I.I., Umoh, J.U., Sa’idu , L., Mera ,U.M. and Edache J. A., 2009. Seroprevalence, seasonal occurrence and clinical manifestation of Newcastle disease in rural household chickens in plateau state, Nigeria, International Journal of Poultry Science, 8, 200-204 
Nwanta, J.A., Umoh, J.U., Abdu, P.A., Ajogi, I. and Alli-Balogun, J.K., 2006. Management of losses and Newcastle disease in rural poultry in Kaduna State, Nigeria, Nigerian Journal of Animal Production, 33, 274-285.

OIE, 2008. Newcastle Disease. In manual of diagnostic tests and vaccines for terrestrial Animals. Chapter 2.3. 14. Organization for world Animal Health, (available at http://www.oie.int/eng/norms/MMANUAL/2008.pdf/2.03.04_NEWCASTLE_DIS.PDF)

Orajaka, L.J.E., Adene, D.F., Anene, B.M. and Onuoha, H.A., 1999. Sero-prevalence of Newcastle disease in local chicken from southeast savannah Zone of Nigeria, Revue d'Elevage et de Medecine Veterinaire des Pays Tropicaux, 52, 185-188.

Otim, M.O., Christensen, H., Jørgensen, P.H., Handberg, K.J. and Bisgaard, M., 2004. Molecular characterization and phylogenetic study of Newcastle disease virus isolates from recent outbreaks in Eastern Uganda, Journal of Clinical Microbiology, 42, 2802-2805.

Rasamoelina Andriamanivo, H., Lancelot, R., Maminiaina, O.F., Rakotondrafara, T.F., Jourdan, M., Renard, J.F., Gil, P., Servan de Almeida, R., Albina, E., Martinez, D., Tillard, E., Rakotondravao, R. and Chevalier, V., 2012. Risk factors for avian influenza and Newcastle disease in smallholder farming systems, Madagascar highlands, Preventive Veterinary Medicine, 104:114-124.

Rao, J.N.K. and Scott, A.J., 1984. On chi-squared tests for multiway contingency tables with cell proportions estimated from survey data, Annals of Statistics, 12, 46-60.

Sa'idu, L., Abdu, P.A., Tekdek, L.B., Umoh, J.U., Usman, M. and Oladele, S.B., 2006. Newcastle disease in Nigeria, Nigerian Veterinary Journal, 27, 23-32.

Samuel, J.L. and Spradbrow, P.B., 1989. Persistence of V4 strain of Newcastle disease virus in an open-range flock of chicken, Veterinary Record, 124,193-196 
Seal, B.S., King, D.J and Bennett, J.D., 1995. Characterization of Newcastle disease virus isolates by reverse transcription PCR coupled to direct nucleotide sequencing and development of sequence database for pathotype prediction and molecular epidemiological analysis, Journal of Clinical Microbiology, 33, 2624-2630.

Serrão,E., Meers, J., Pym, R., Copland, R., Eagles, D. and Henning, J., 2012. Prevalence and incidence of Newcastle disease and prevalence of Avian influenza infection of scavenging village chickens in Timor-Lesté, Preventive Veterinary Medicine, 104, 301-308

Servan de Almeida, R., Maminiaina, O.M., Gil, P., Hammoumi, S., Molia, S., Chevalier V., Okob, M., Harentsoaniain, H., Andriamanivo, R., Traoré, A., Samaké, K., Diarra, A., Grillet, C., Martinez, D. and Albina, E., 2009. Africa, a reservoir of new virulent strains of Newcastle disease virus? Vaccine, 27, 3127-3129.

Singh, K, Jinda, N. Gupta, S.L., Gupta, A.K. and Mittal, D., 2005. Detection of Newcastle disease Virus from the field outbreaks in poultry by reverse Transcription-polymerase Chain Reaction, International Journal of Poultry Science, 4, 472-475.

Snoeck, C.J., Ducatez, M.F., Owoade, A.A., Faleke, O.O., Alkali, B.R., Tahita , M.C., Tarnagda, Z., Ouedraogo, J.B., Maikano, I., Mbah, P.O., Kremer, J.R. and Muller, C.P., 2009. Newcastle disease virus in West Africa: new virulent strains identified in non-commercial farms, Archives of Virology, 154, 47-54.

Spradbrow, P.B., Ibrahim, A.L., Chulan, U., Milliken, G., Shapcott, R. and Kingston, D., 1980. The response of Australian chickens naturally infected with avirulent Newcastle disease virus to challenge with velogenic Newcastle disease virus, Australian Veterinary Journal, 56, 580584 
Tadesse, S., Ashenafi, A. and Aschalew, Z., 2005. Seroprevalence study of Newcastle disease in local chickens in central Ethiopia, International Journal of Applied Research in Veterinary Medicine, 3, 25-29.

Turner, A.J., Hanson, R.P. and Spalatin, J., 1976. Simulated natural infection of chickens with Australian lentogenic Newcastle disease virus and subsequent challenge with virulent virus, Australian Veterinary Journal, 52, 524-528.

Van Boven, M., Bouma, A., Fabri, T.H.F., Katsma, E., Hartog, L. and Koch, G., 2008. Herd immunity to Newcastle disease virus in poultry by vaccination, Avian Pathology, 37, 1-5.

Westbury, H.A., Parsons, G. and Allan, W.H., 1984. Duration of excretion of virulent Newcastle disease virus following challenge of chickens with different titres of serum antibody to the virus, Australian Veterinary Journal, 61, 44-46.

Wise, M.G., Suarez, D.L., Seal, B.S., Pedersen, J.C., Senne, D.A., King, D.J., Kapczynski, D.R. and Spackman, E., 2004. Development of a real-time reverse-transcription PCR for detection of Newcastle disease virus RNA in clinical samples, Journal of Clinical Microbiology, 42, 329-338.

Zeleke, A., Sori, T., Gelaye, E. and Ayelet, G., 2005. Newcastle disease in Village Chickens in the southern and Rift valley Districts in Ethiopia, International Journal of Poultry Science, 4, 507-510. 